\title{
Tailor the antibacterial efficiency of copper alloys by oxidation: when to and when not to
}

\author{
Jiaqi Luo ${ }^{1,2,3, *}$ (D), Aisha Ahmed ${ }^{1,2}$, Jean-François Pierson², and Frank Mücklich ${ }^{1}$ \\ ${ }^{1}$ Functional Materials, Saarland University, 66123 Saarbruecken, Germany \\ ${ }^{2}$ Université de Lorraine, CNRS, IJL, 54000 Nancy, France \\ ${ }^{3}$ Present address: The Open Innovation Hub for Antimicrobial Surfaces, Surface Science Research Centre, Department of Chemistry, \\ University of Liverpool, Liverpool L69 3BX, UK
}

Received: 21 August 2021

Accepted: 5 January 2022

Published online:

20 January 2022

(C) The Author(s) 2022

\begin{abstract}
Copper and its relevant species, such as oxides and many alloys, have been recognised as potential antibacterial surfaces. Despite the relatively low antibacterial efficacy of cuprous oxide $\left(\mathrm{Cu}_{2} \mathrm{O}\right)$ compared to pure copper, it is still worth consideration in some scenarios. Taking copper-nickel co-sputtered thin films with two copper contents (55 and 92 at.\%) as examples, this work investigated the potential of oxidation in altering the antibacterial behaviour of copper alloy surfaces. By heat treatment at $200-250{ }^{\circ} \mathrm{C}$ for $20-24 \mathrm{~h}$, a layer mainly composed of $\mathrm{Cu}_{2} \mathrm{O}$ was successfully fabricated on the top of the $\mathrm{Cu}-\mathrm{Ni}$ alloys. Antibacterial efficiency against Escherichia coli in $1 \mathrm{~h}$ was obtained by the droplet method and further compared. The coupons with 92 at.\% copper became less effective after oxidation: the reduction rate declines from 97.0 to $74.3 \%$; whereas the coupons with 55 at.\% copper showed a large increase after oxidation, rising from 15.0 to $66.8 \%$. The experiments described herein reveal a promising concept of oxidation in enhancing the less effective copper alloy surfaces for antibacterial applications.
\end{abstract}

Handling Editor: P. Nash.

Address correspondence to E-mail: jiaqi.luo@liverpool.ac.uk 


\section{GRAPHICAL ABSTRACT}

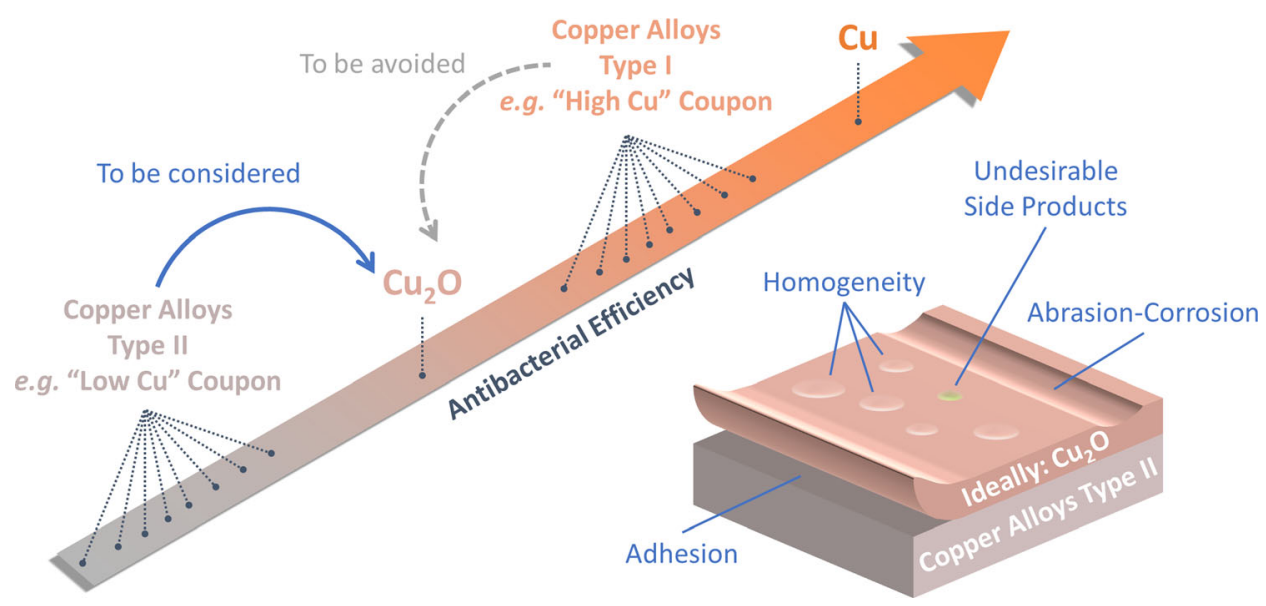

\section{Introduction}

Copper and copper alloys have been extensively investigated in recent years in terms of their antibacterial activity [1-3]. These metallic copper surfaces are excellent candidates in many scenarios, amongst which frequently touched surfaces have been highlighted, as they can be contaminated and further transmit deadly pathogens [4-7]. In our daily lives, antibacterial surfaces installed in public environments such as in transportations and buildings would be extremely helpful since timely cleaning is not always available. For the same reason, there is high expectation and demand in health care facilities, as it could become the decisive factor in combating with healthcare-associated infections (HAIs) that are strongly related to cross-contamination on surfaces.

The knowledge regarding antibacterial mechanisms of copper is being developed, which most of the time, is linked with the ionic copper released from the surfaces. Cuprous ions $\left(\mathrm{Cu}^{+}\right)$could directly damage enzymes by replacing iron in their iron-sulphur clusters [8] or exhibit antibacterial effect indirectly by forming reactive oxygen species (ROS) [9]. Therefore, the antibacterial efficiency presented by the metallic copper surfaces, to a considerable degree, depends on how efficiently copper ions are released from the surfaces. This efficiency is certainly environment-dependent, for example, it can be evidently enhanced in a relatively corrosive environment in the existence of chloride [10]. Nevertheless, the chemical composition of the surfaces also plays an important role, as some alloying elements are originally designed to reduce the global corrosion tendency [11]. As a result, a phenomenon has been frequently observed on copper alloys: their antibacterial efficiency is poorer than the one of pure copper [12]. A huge range of metallic copper surfaces prepared with antibacterial properties have been assessed, including pure copper [13], Cu-Sn [14], Cu-Ag [15], $\mathrm{Cu}-\mathrm{Zr}$ [16], Cu-Zr-Ag [17, 18], etc.

In addition to the metallic copper surfaces, copper oxides, regardless of their oxidation state: cupric oxide $(\mathrm{CuO})$ or cuprous oxide $\left(\mathrm{Cu}_{2} \mathrm{O}\right)$, have both shown antibacterial activity, although usually being considered less effective than pure copper [19-21]. As copper oxides can also release copper ions, even though by dissolution instead of corrosion, they do share similar antibacterial mechanisms as the metallic copper surfaces. Besides, extra amount of ROS could be produced via photocatalytic effect introduced by their semiconductor characteristics [22], assisting the antibacterial process. Copper oxide surfaces with antibacterial activity have been successfully synthesised by various methods, e.g. chemical vapour deposition [20], sputtering [21], wet chemical method 
[23], hydrothermal method [24], and spin coating [25].

Apart from depositing an extra oxide layer on the pre-existing objects, such oxides can be obtained by directly transforming the metallic copper surfaces through specific oxidation processes. Several attempts have been recently reported, in order to evaluate the impacts of such sort of oxidation on the metallic copper alloys as well as their antibacterial efficiency [26, 27]. More precisely, it is usually the potential undesirable degradation of antibacterial efficiency that draws the attention of researchers. However, considering that the antibacterial efficiency of copper alloys could actually vary on a quite large scale [1], there might be several copper alloys that own poorer antibacterial efficacy than copper oxides. In these cases, oxidation of these surfaces would not necessarily become an unwelcome phenomenon. Instead, it can be the key to improve the antibacterial activity of those copper alloy surface, meanwhile preserving the advantage of metallurgical processing or mechanical properties introduced by alloying elements.

Consequently, we designed a scenario to verify this hypothesis. Copper-nickel thin films were produced by co-sputtering method, with two different copper contents, representing copper alloys with antibacterial efficiency in two ranges: intrinsically better or worse than $\mathrm{Cu}_{2} \mathrm{O}$. These thin films were thermally oxidised, aiming to form a layer of $\mathrm{Cu}_{2} \mathrm{O}$ on the surface. Their antibacterial efficacy against $E$. coli was analysed, confirming the potential of this strategy.

\section{Materials and methods}

\section{Thin film deposition}

Copper-nickel thin films were deposited on microscope glass slides by magnetron co-sputtering technique. Before being transferred into the sputtering chamber, the substrates were cleaned with ethanol in an ultrasonic bath. During deposition, the sputtering pressure was maintained at $0.4 \mathrm{~Pa}$, whilst the flow rate of argon was $50 \mathrm{sccm}$. The distance between the substrate and the $\mathrm{Cu}$ target ( $2^{\prime \prime}$ diameter and $99.99 \%$ purity) and Ni target ( $2^{\prime \prime}$ diameter and $99.99 \%$ purity) were 59 and $66 \mathrm{~mm}$, respectively. The $\mathrm{Cu}$ content was controlled by adjusting the sputtering current of the $\mathrm{Cu}$ target by a DC generator (MDX-1.5 K,
Advanced Energy): it was $0.20 \mathrm{~A}$ for high $\mathrm{Cu}$ content coupons (hereafter "High $\mathrm{Cu}^{\prime}$ ) and $0.05 \mathrm{~A}$ for low $\mathrm{Cu}$ content coupons (hereafter "Low $\mathrm{Cu}^{\prime}$ ). Sputtering of $\mathrm{Ni}$ target was performed with a constant current 0.10 A for both sets, by a pulsed-DC generator (Pinnacle, Advanced Energy), whose frequency and off time were $50 \mathrm{kHz}$ and $4 \mathrm{~ms}$, respectively. The total deposition time was $10 \mathrm{~min}$ for the $\mathrm{High} \mathrm{Cu}$ and $20 \mathrm{~min}$ for the Low $\mathrm{Cu}$. These thin films were deposited without intentional heating of the substrate holder.

\section{Heat treatment}

Formation of oxides on the above-mentioned thin films were processed in a heating oven (UT 6120, Heraeus). Coupons were placed in the oven at room temperature, and the heat treatment was counted from the time the oven reached the specific temperatures. There were two sets of heat treatment parameters: (1) $200{ }^{\circ} \mathrm{C}$ for $20 \mathrm{~h}$ and (2) $250{ }^{\circ} \mathrm{C}$ for $24 \mathrm{~h}$. At the end of this time, the oven was shut down and the coupons were taken out after the oven reached room temperature. The ventilation of the oven was maintained at the lowest level before the oven was shut down. According to their original copper contents, they are called "High $\mathrm{Cu} \mathrm{HT}$ " and "Low $\mathrm{Cu} \mathrm{HT}$ " hereafter.

\section{Solutions}

Phosphate-buffered saline (PBS) was prepared using $\mathrm{NaH}_{2} \mathrm{PO}_{4} \cdot 1 \mathrm{H}_{2} \mathrm{O}$ (Merck, Germany, final concentration $0.01 \mathrm{M}), \mathrm{NaCl}$ (VWR, Germany, final concentration $0.14 \mathrm{M}$ ) and pure water for analysis, and its $\mathrm{pH}$ value was adjusted by adding $\mathrm{NaOH}$ to 7.4 . It was sterilised after preparation.

\section{Surface characterisation}

High resolution grazing incidence $X$-ray diffractometer (GIXRD, $\mathrm{Cu} \mathrm{K} \alpha$ source with a wavelength of $1.54 \AA$ at $1^{\circ}$ grazing angle, PANalytical X'Pert PROMPD) was used to determine the phases of as-deposited and heat-treated thin films. The following diffraction data are used to index: JCDPS\#04-0836 for $\mathrm{Cu}$, JCPDS\#75-1531 for $\mathrm{Cu}_{2} \mathrm{O}$, and JCPDS\#04-0835 for $\mathrm{NiO}$. Different functions of scanning electron microscope (SEM, Helios NanoLab600, FEI) were employed at $5 \mathrm{kV}$ : both Everhart-Thornley detector and Through-the-Lens detector were applied to 
examine the top-surface of the coupons, whilst their global or local chemical composition was obtained by energy-dispersive X-ray spectroscopy (EDS). Image classification and analysis was processed with Fiji [28], with which the "Find Maxima" algorithm was applied.

\section{Antibacterial efficiency determination}

The antibacterial activity on the coupon surface was tested via the droplet method [29]. E. coli WT K12 (BW25113) strain were grown overnight aerobically in Lysogeny broth (LB) medium at $37^{\circ} \mathrm{C}$ in a water bath with a speed of $220 \mathrm{rpm}$. Next day, the bacterial culture was taken out and centrifuged at $5000 \times \mathrm{g}$ to separate the stationary cells. The centrifugation process was repeated three times with PBS using the same parameters. Finally, the stationary cells were resuspended in PBS to prepare the bacterial suspension. Following this, $20 \mu \mathrm{L}$ of the suspension was applied on the tested surfaces in the form of droplet. The test was carried out in a high humid environment at room temperature for a $1 \mathrm{~h}$ duration. At the end of this time, $10 \mu \mathrm{L}$ of the suspension was retreated from the droplet after repetitive pipetting, then serially diluted in PBS and finally spread on LB agar plates. The plates were stored in an incubator at $37^{\circ} \mathrm{C}$ for $24 \mathrm{~h}$. Finally, the colony-forming units (cfu) were counted to enumerate the bacteria of the suspension taken. For negative control, the $\mathrm{cfu} / \mathrm{ml}$ value from the test on the stainless steel was chosen for the section "Heat treatment at $200{ }^{\circ} \mathrm{C}$ is only successful for the High $\mathrm{Cu}^{\prime \prime}$ and the original $\mathrm{cfu} / \mathrm{ml}$ value of the suspension for the section "Heat treatment at $250{ }^{\circ} \mathrm{C}$ turned the Low $\mathrm{Cu}$ to $\mathrm{Cu}_{2} \mathrm{O}^{\prime \prime}$. Reduction rate is calculated by dividing the number of deactivated bacteria (i.e. difference of the cfu between the values of negative control and the values obtained in $1 \mathrm{~h}$ ) by the values of negative control.

\section{Results and discussion}

\section{Characterisation of as-deposited Copper- nickel thin films}

Prior to investigating the effects of heat treatment, it is important to understand the features of the as-deposited thin films. Figure 1a presents the elemental analysis of the $\mathrm{Cu}-\mathrm{Ni}$ co-sputtered thin films prepared with two currents applied to the $\mathrm{Cu}$ target. In the spectrum obtained from the High $\mathrm{Cu}$, the $\mathrm{CuL}$ peak dominates the $\mathrm{X}$-ray distribution, whilst the $\mathrm{NiL}$ peak can hardly be distinguished. On the other hand, the NiL peak becomes obvious in the case of the Low $\mathrm{Cu}$. Quantification of these two elements after ZAF correction can be found in the inset: 92 at.\% for the High $\mathrm{Cu}$ and 55 at.\% for the Low $\mathrm{Cu}$. However, it must be noticed that, these values may not precisely represent the actual composition because of the overlap of these two peaks, especially in the case of the High $\mathrm{Cu}$ (find detailed explanation in SI Fig. 1).

X-ray diffractograms shown in Fig. $1 \mathrm{~b}$ further reveal the phase composition of the coupons. The broad diffraction peaks located from 15 to $40^{\circ}$ originate from the amorphous glass substrate. This peak was less obvious for the High $\mathrm{Cu}$, simply due to the greater thickness of the thin film (SI Fig. 2). For the same reason, the other diffraction peaks that can be indexed to $\mathrm{Cu}$, are more intense in the diffractogram of the High $\mathrm{Cu}$. Besides, on the diffractogram of the Low $\mathrm{Cu}$, shift of the $\mathrm{Cu}$ diffraction peaks to higher angle can be observed as highlighted in the inset. This phenomenon is associated to the substitution of $\mathrm{Cu}$ atoms by $\mathrm{Ni}$ atoms in the $\mathrm{fcc}$ solid solution. Because the metallic $\mathrm{Ni}$ atoms is smaller than the $\mathrm{Cu}$ ones, an increase of $\mathrm{Ni}$ content leads to a decrease of the fcc lattice constant, causing a shift towards higher diffraction angle according to Bragg's law.

Figure 1c-e further compare the morphology of the as-deposited thin films. It is clear that a larger grain size is observed on the High $\mathrm{Cu}$, whereas that shown on the Low $\mathrm{Cu}$ already reaches the limit of resolution at that operating conditions. For the same reason, the statistics from image processing indicate a relatively high fraction in the ultrasmall region, which could come from the inevitable error introduced by the blurry boundaries. The discrepancy of two thin films could be attributed to the thickness, i.e. the growth process of thin films, where the Low $\mathrm{Cu}$ could be closer to its nucleation regime and therefore with a finer microstructure.

To conclude, the $\mathrm{Cu}$ content is not the sole difference existing between two set of $\mathrm{Cu}-\mathrm{Ni}$ thin films. However, it can be seen from the following sections that the influence of other parameters is not concerning in the present study. 
(a)
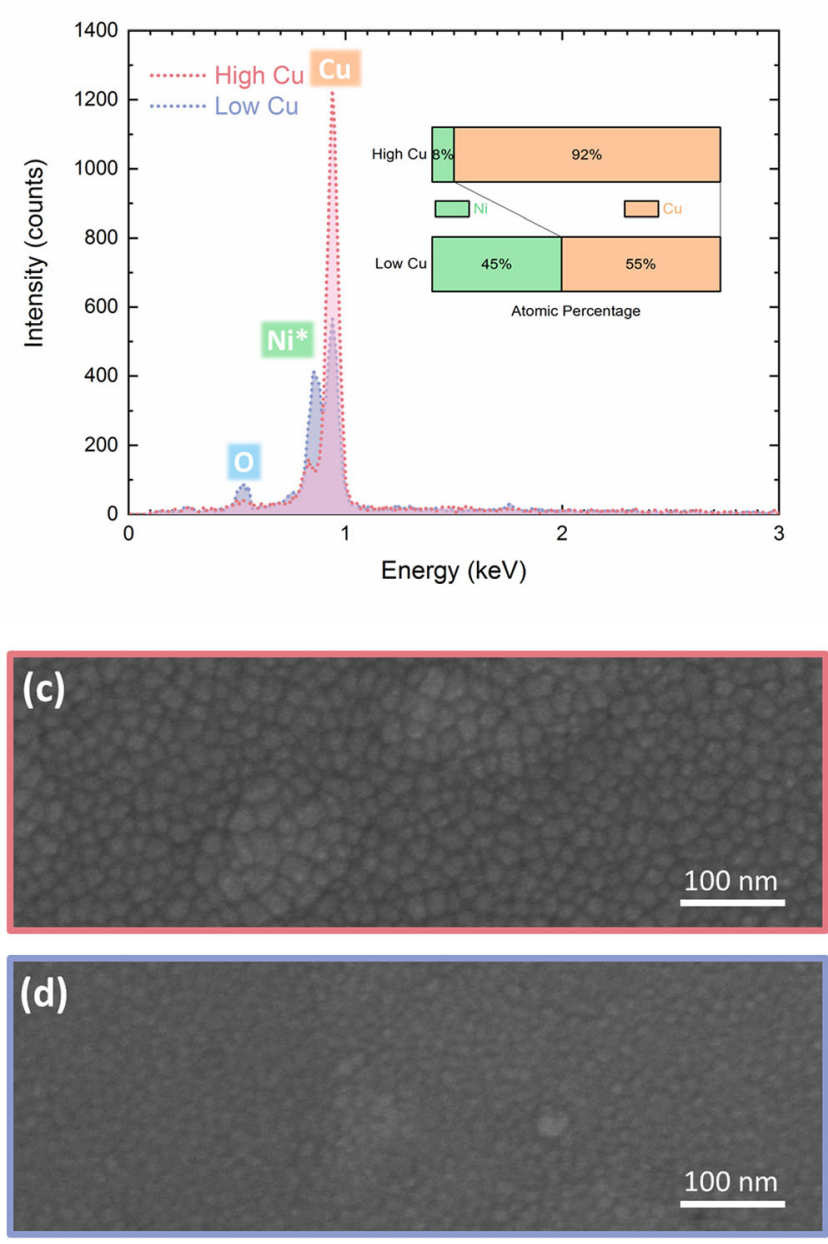

Figure 1 EDS spectra (a) collected from the coupons, with inset indicating the quantitative results after ZAF correction where $\mathrm{Ni}$ and $\mathrm{Cu}$ were selected. The label of $\mathrm{Ni}$ is marked with star in order to remind the readers of the likely overlap between $\mathrm{NiL}$ and $\mathrm{CuL}$. High resolution GIXRD results (b) of as-deposited coupons, with

\section{Heat treatment at $200{ }^{\circ} \mathrm{C}$ is only successful for the High $\mathrm{Cu}$}

Heat treatment in ambient atmosphere at $200{ }^{\circ} \mathrm{C}$ has been demonstrated to form a layer of $\mathrm{Cu}_{2} \mathrm{O}$ on top of pure $\mathrm{Cu}$ samples [19]. As a result, heat treatment at this temperature was firstly applied on $\mathrm{Cu}-\mathrm{Ni}$ cosputtered thin films, aiming to oxidise their outermost part and to obtain a layer mainly composed of $\mathrm{Cu}_{2} \mathrm{O}$.

Phase analysis of the heat-treated thin films can be found in Fig. 2a. For the High Cu HT, heat treatment introduces three extra and distinct peaks in its diffractogram, namely the (110), (111), and (220)
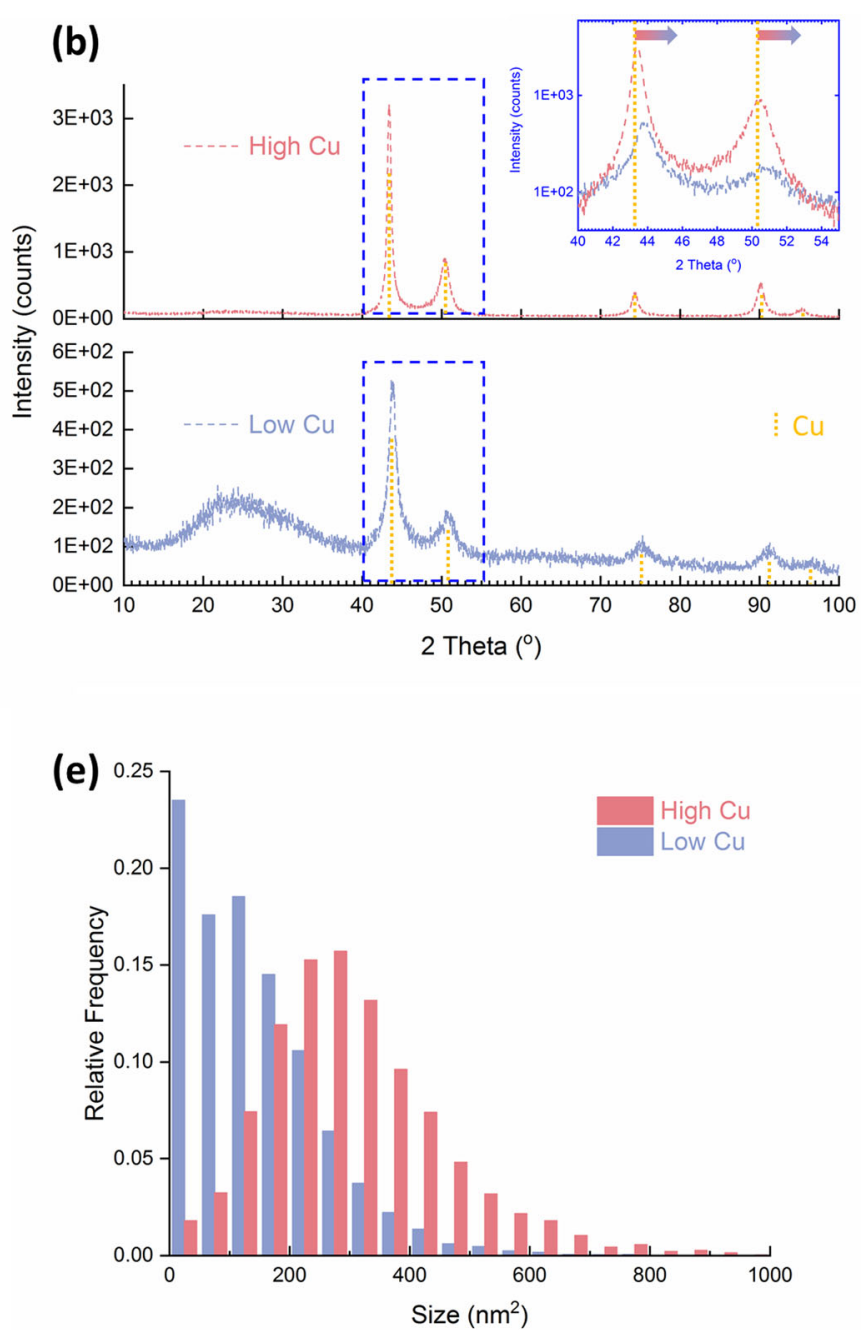

inset that compares the positions of (111) and (200) diffractions with pure copper (JCDPS\#04-0836). Representative high resolution SEM images of as-deposited the High $\mathrm{Cu}$ (c) and the Low $\mathrm{Cu}$ (d). Histogram (e) summaries the distribution of the lateral size of the grains calculated from SEM images.

diffraction peaks of $\mathrm{Cu}_{2} \mathrm{O}$. However, it has to be admitted that the formation of nickel oxide $(\mathrm{NiO})$ should not be ruled out, based on the greater affinity of $\mathrm{Ni}$ atoms for oxygen [30]. The fact that it is hardly detectable can be attributed to the low Ni concentration in the alloy.

On the other hand, the attempt to form $\mathrm{Cu}_{2} \mathrm{O}$ on the Low $\mathrm{Cu}$ HT seems to be unsuccessful: no additional diffraction peaks can be identified clearly or indexed to $\mathrm{Cu}_{2} \mathrm{O}$ (or $\mathrm{NiO}$ ). The reason why the current heat treatment parameters might not be effective enough to form an observable amount of $\mathrm{Cu}_{2} \mathrm{O}$ could be associated with the addition of $\mathrm{Ni}$. Previous research performed at elevated temperature (around 

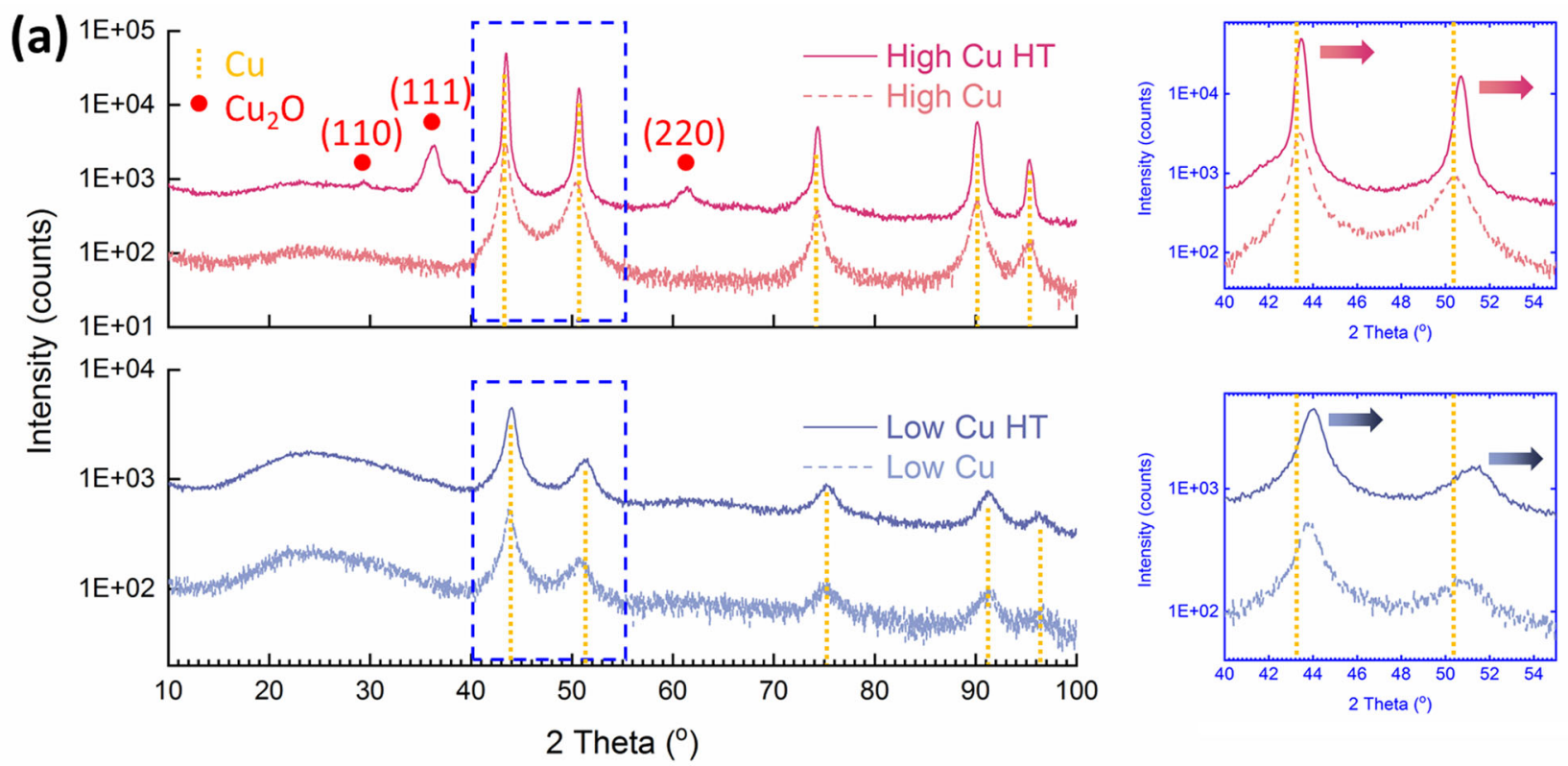

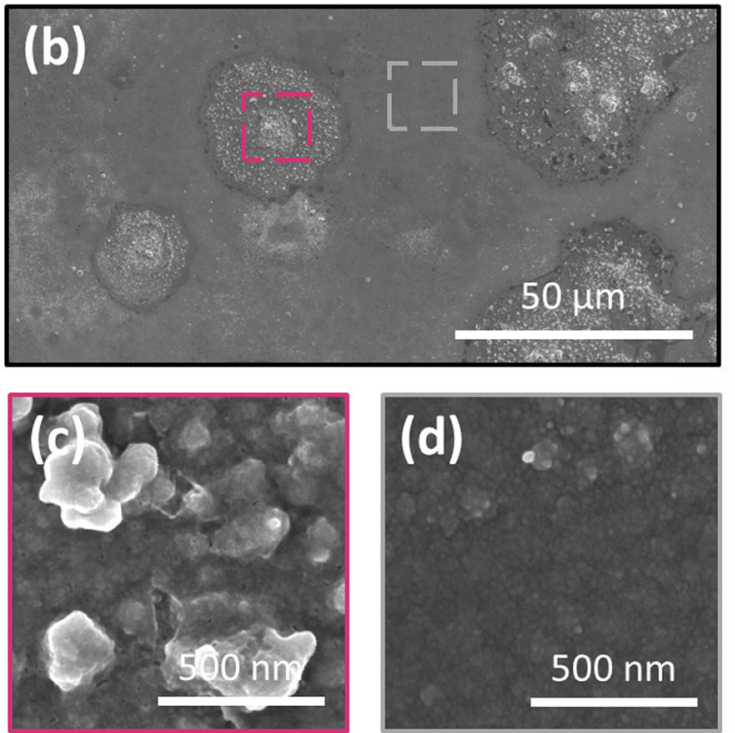

Figure 2 High resolution GIXRD results (a) of $200{ }^{\circ} \mathrm{C}$ heattreated coupons ("High $\mathrm{Cu} \mathrm{HT"} \mathrm{and} \mathrm{"Low} \mathrm{Cu} \mathrm{HT")} \mathrm{and} \mathrm{their}$ original as-deposited coupons ("High $\mathrm{Cu}$ " and "Low $\mathrm{Cu}$ " that have been shown in Fig. 1) for comparison. $\mathrm{Cu}_{2} \mathrm{O}$ (JCPDS\#75-1531) was applied to index the additional peaks. Enlarged spectra at the right side compare the positions of (111) and (200) diffractions with pure copper (JCDPS\#04-0836). Representative SEM image

$450{ }^{\circ} \mathrm{C}$ ) has observed a prolonged nucleation period for $\mathrm{Cu}_{2} \mathrm{O}$ as the concentration of $\mathrm{Ni}$ rises in the low copper content regime [31].

In addition, in both cases, the diffraction peaks from $\mathrm{Cu}$ can still be easily recorded, meaning that a substantial portion of these heat-treated thin films is still in the unreacted metallic state. These $\mathrm{Cu}$

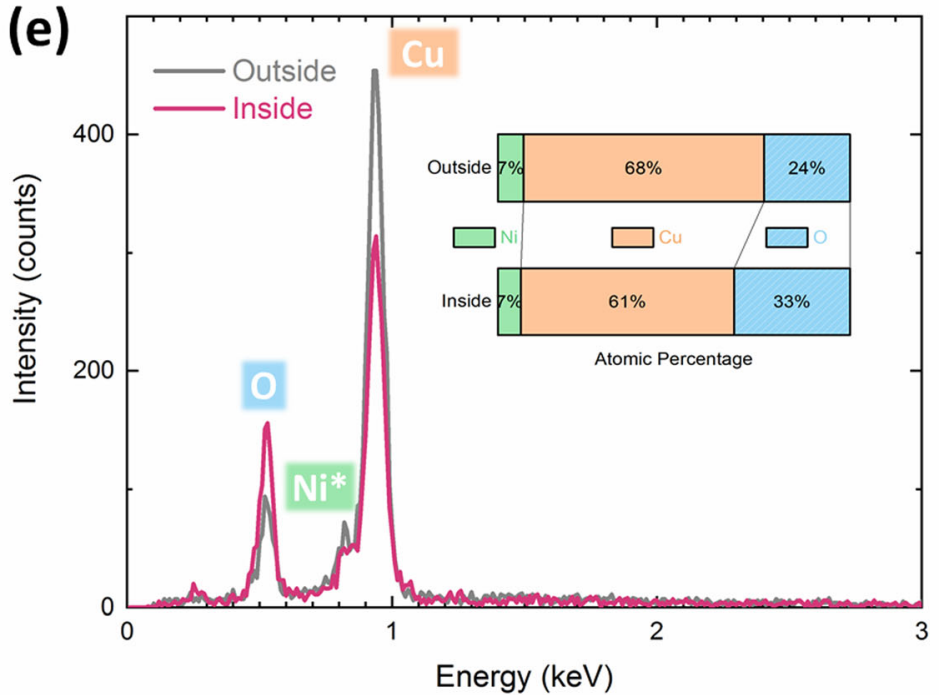

(b) and high resolution SEM images (c, d) of two different regions found on the High $\mathrm{Cu}$ HT. EDS spectra (e) were collected from the regions that marked by squares in (b), with inset indicating the average quantitative results based on the data shown in SI Fig. 3. The label of $\mathrm{Ni}$ is marked with star in order to remind the readers of the likely overlap between NiL and CuL.

diffraction peaks exhibit a shift to higher angle. As discussed in the above section, the shift of these metallic diffraction peaks corresponds to the shrinkage of fcc lattice. It is true that annealing tends to enhance diffusion, remove defects, improve the crystallinity, and thus results in relaxation of the internal stress. But if the shrinkage of glass substrate 
due to annealing is more significant than that of thin films, then an external compressive state would still be introduced on the thin films. Alternatively, this compressive state can be related to the formation of oxides. The Pilling-Bedworth ratio of $\mathrm{Cu}_{2} \mathrm{O}$ and $\mathrm{NiO}$ are both greater than 1 , implying that an increase in volume is expected once $\mathrm{Cu}$ or $\mathrm{Ni}$ transforms to its oxide. It could therefore introduce compressive stress to the unreacted metallic thin films.

Although the formation of $\mathrm{Cu}_{2} \mathrm{O}$ on the High $\mathrm{Cu}$ HT was successful, interestingly, the oxidation is not homogeneous. Figure $2 \mathrm{~b}-\mathrm{e}$ compare the evident morphological features: there are some (mostly round) regions owning coarser and upheaved particles, whereas the other regions are finer and flatter. Besides, stronger $\mathrm{X}$-ray signal of oxygen can be found in the former region, representing the formation of thicker or denser oxide. It has to be noted that the atomic percentages calculated (as well as those to be shown in the following section) do not represent the chemical composition of any phases in any regions. This is because the $\mathrm{X}$-ray signal could originate from both the oxide layer and the underneath co-sputtered thin films, and it therefore does not satisfy the premise of quantification under ZAF correction. Although these micron-scale features are not going to be further discussed with the global antibacterial activity, recent studies from different research groups did imply their possible roles in assisting bacteria deactivation $[32,33]$.

As for the antibacterial behaviour, previous studies have shown the significant effect of oxide formation on pure copper surfaces [19,27]. Similar tests were now conducted on both $\mathrm{Cu}-\mathrm{Ni}$ thin films, both the asdeposited state and the heat-treated state. Figure 3 shows the survival and reduction rate of E. coli after $1 \mathrm{~h}$ contact time compared to stainless steel. The results show that the High $\mathrm{Cu}$ killed bacteria most efficiently (96.8\%), whilst its heat-treated state, the High Cu HT became less efficient (77.9\%). This can be attributed to the formation of $\mathrm{Cu}_{2} \mathrm{O}$ on the High $\mathrm{Cu}$ HT: the intrinsic antibacterial efficiency of the High $\mathrm{Cu}$ is higher than that of $\mathrm{Cu}_{2} \mathrm{O}$, thus the oxide coverage on the surface compromises the antibacterial behaviour.

The Low $\mathrm{Cu}$, on the other hand, exhibits a relatively poor antibacterial efficacy: the reduction rate increases from $33.7 \%$ to $44.2 \%$ after heat treatment. This could be a neglectable enhance, given that the standard deviations are relatively huge. This can be attributed to the insufficient oxidation of the surface: if the surface was completely transformed into $\mathrm{Cu}_{2} \mathrm{O}$ only (as in the case of the High $\mathrm{Cu} \mathrm{HT}$ ), then an antibacterial efficiency or reduction rate similar to the High $\mathrm{Cu}$ HT should have been observed. That being said, other modifications in terms of microstructural or surface properties introduced by the thermal oxidation process (i.e. annealing process) could also contribute to this neglectable change in antibacterial efficiency. To sum up, it is still necessary to find another approach that can lead to a sufficient $\mathrm{Cu}_{2} \mathrm{O}$ formation on the Low $\mathrm{Cu}$, in order to accomplish verification of the concept proposed.

\section{Heat treatment at $250^{\circ} \mathrm{C}$ turned the Low Cu to $\mathrm{Cu}_{2} \mathrm{O}$}

Since the heat treatment parameters described in the above section failed to oxidise the Low $\mathrm{Cu}$ (even with prolonged period, see SI Fig. 4), thermal oxidation at a slightly high temperature $\left(250{ }^{\circ} \mathrm{C}\right)$ was proceeded as it often increases the tendency to form oxides $[34,35]$, meanwhile avoiding the formation of lessdesirable $\mathrm{CuO}$ [36]. Although it is unnecessary to carry out this heat treatment on the High $\mathrm{Cu}$ (as the designed $\mathrm{Cu}_{2} \mathrm{O}$ was already obtained at $200{ }^{\circ} \mathrm{C}$ and served its purpose), it was still included here for better comparison.

The diffractograms in Fig. 4a demonstrate the efficacy of this heat treatment at $250{ }^{\circ} \mathrm{C}$ on both coupons. $\mathrm{Cu}_{2} \mathrm{O}$ oxide still dominates the oxide species formed on the High Cu HT, but most excitingly, the very same oxide finally appears on the Low $\mathrm{Cu}$ HT. Additionally, a relatively tiny and broad diffraction peak was recorded and can be assigned to (220) diffraction of $\mathrm{NiO}$. And again, such an annealing process introduces a shift of $\mathrm{Cu}$ diffraction peaks to higher angle for similar reasons discussed in the previous section.

Similarly, Fig. $4 \mathrm{~b}-\mathrm{d}$ show the localised strong oxidation phenomenon observed on the Low $\mathrm{Cu}$ HT (and the High $\mathrm{Cu}$ HT as well, see SI Fig. 6). The regions outside are also oxidised, but less in amount. Since in the case of the Low $\mathrm{Cu} \mathrm{HT}$, X-ray radiation of $\mathrm{CuL}$ and NiL can be easily differentiated, it is thus clear that a drop of NiL intensity can be recognised inside the strong oxidation regions. This revealed the preferred oxidation of $\mathrm{Cu}$ in these regions.

Regarding the antibacterial behaviour shown in Fig. 5, similar to the results in the previous section, 


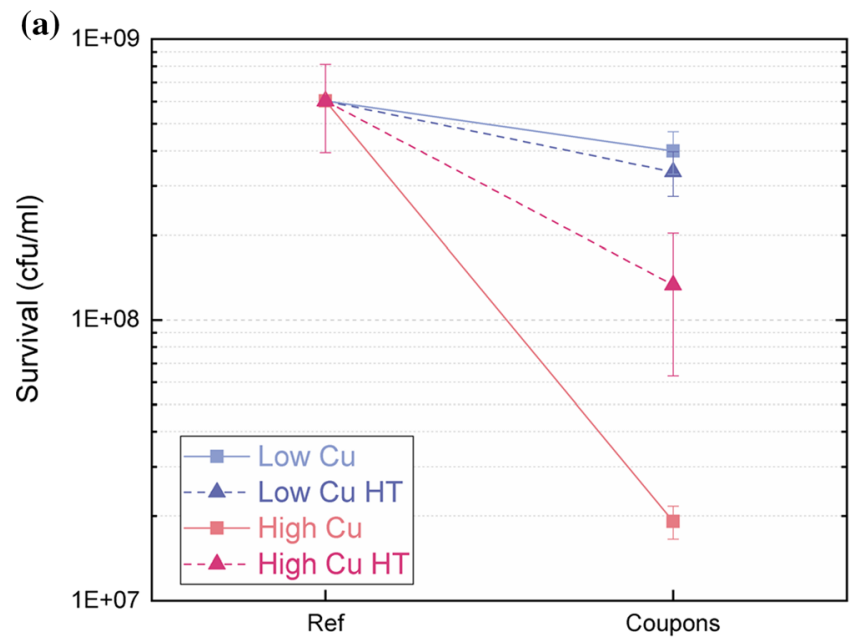

Figure 3 Antibacterial efficiency tests with E. coli on the $200{ }^{\circ} \mathrm{C}$

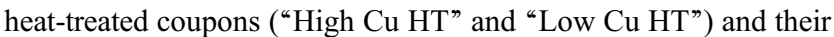
original as-deposited coupons ("High $\mathrm{Cu}$ " and "Low $\mathrm{Cu}$ "): (a) surviving colony-forming units and (b) the reduction rate in

the High $\mathrm{Cu}$ shows the best antibacterial efficiency (97.0\%) amongst the tested coupons, whilst the High $\mathrm{Cu}$ HT endures a decrease (to $74.3 \%$ ) due to surface oxidation. On the other hand, unlike the heat treatment at $200{ }^{\circ} \mathrm{C}$, the number of surviving bacteria on the Low $\mathrm{Cu}$ HT decreases significantly this time. The reduction rate thus mounts from $15.0 \%$ to $66.8 \%$, which is very close to that obtained from the High $\mathrm{Cu}$ HT. This trend is exactly as expected, as it reflects the successful $\mathrm{Cu}_{2} \mathrm{O}$ formation on the surface of the Low $\mathrm{Cu} \mathrm{HT}$, which thus should show a comparable antibacterial efficiency as the High $\mathrm{Cu}$ HT. Formation of $\mathrm{NiO}$ could be a contributory factor of the slight difference between two heat-treated coupons, because it has not been considered to share comparable antibacterial property as $\mathrm{Cu}_{2} \mathrm{O}$. Besides, the antibacterial efficiency of the heat-treated coupons from this study and the sputtered $\mathrm{Cu}_{2} \mathrm{O}$ coating (around 50\% in $1 \mathrm{~h}$ ) from our previous study [21] are just comparable but not entirely identical. This once again suggests that the antibacterial property does not depend on chemical/phase composition only, but possibly also on the minor effects of the microstructural or surface parameters, which may still require further investigation.

It is true that there are some discrepancies compared to the reduction rates obtained in the first heat treatment trial, e.g. the same Low $\mathrm{Cu}$ showed only $15 \%$ in this trial but $33.7 \%$ in the first trial. This could be introduced by the selection of the negative control (b)

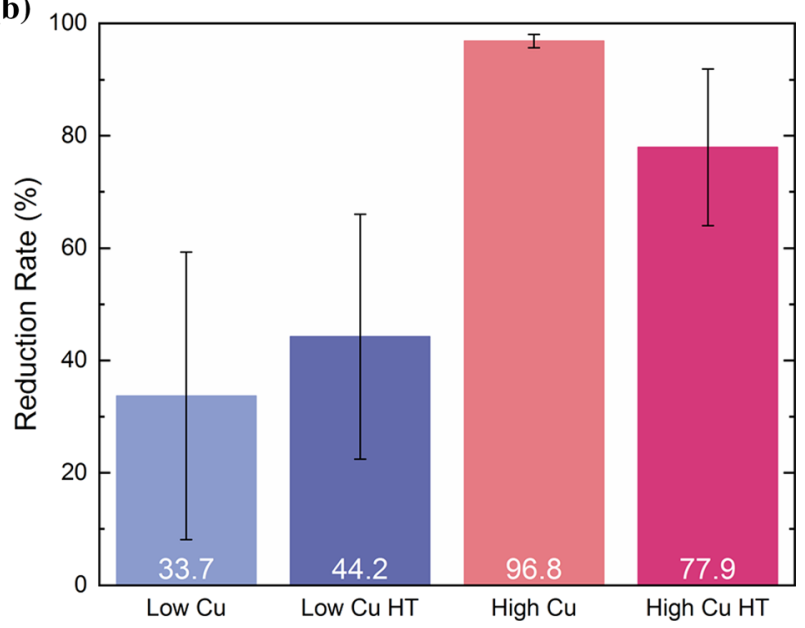

$1 \mathrm{~h}$. The cfu obtained on stainless steel is set as the negative control. The error bars indicate the standard deviation calculated from three measurements. The straight lines in (a) are only added for guiding the eyes.

(stainless steel or the original suspension), or the possible difference in the original concentration of the bacterial suspension $[37,38]$, etc. The slight decrease obtained from the High $\mathrm{Cu}$ HT $(74.3 \%$ in this trial but $77.9 \%$ in the first trial) could be attributed to the same reason, or other slight intrinsic differences between two High $\mathrm{Cu}$ HT surfaces. Nevertheless, none of these affects the concept to be verified: oxidation on certain metallic copper alloy surfaces can truly improve their antibacterial efficiency.

\section{Discussion on this promising strategy and practical insights}

From the above comparison, it is clear that oxidation opens a powerful and simple pathway to tailor the antibacterial performance of the metallic copper alloy surfaces. This is summarised in Fig. 6, where antibacterial efficiency of pure copper and $\mathrm{Cu}_{2} \mathrm{O}$ are set as benchmarks. For the alloys that already show a better reduction rate than $\mathrm{Cu}_{2} \mathrm{O}$ (grouped as "Copper Alloys Type I"), oxidation should be avoided as it impairs their intrinsic antibacterial efficiency, although whether it can be effectively avoided is another issue. On the contrary, for those intrinsically less potent than $\mathrm{Cu}_{2} \mathrm{O}$ (grouped as "Copper Alloys

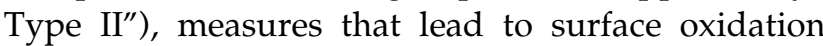
should be considered. By transforming the metallic surfaces into $\mathrm{Cu}_{2} \mathrm{O}$, their antibacterial efficiency can be replaced by that of $\mathrm{Cu}_{2} \mathrm{O}$. 

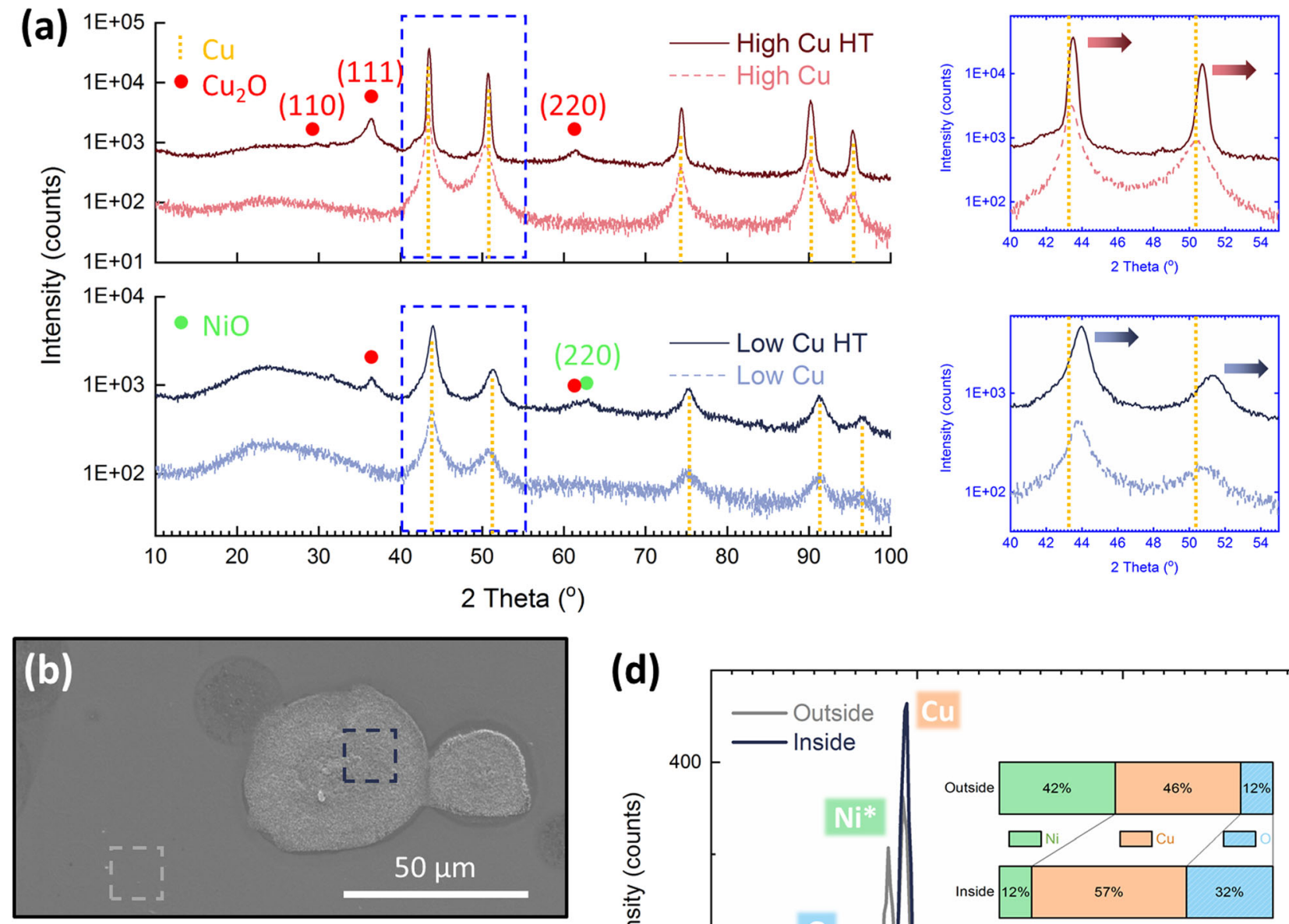

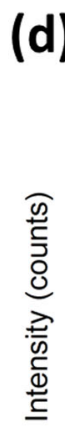
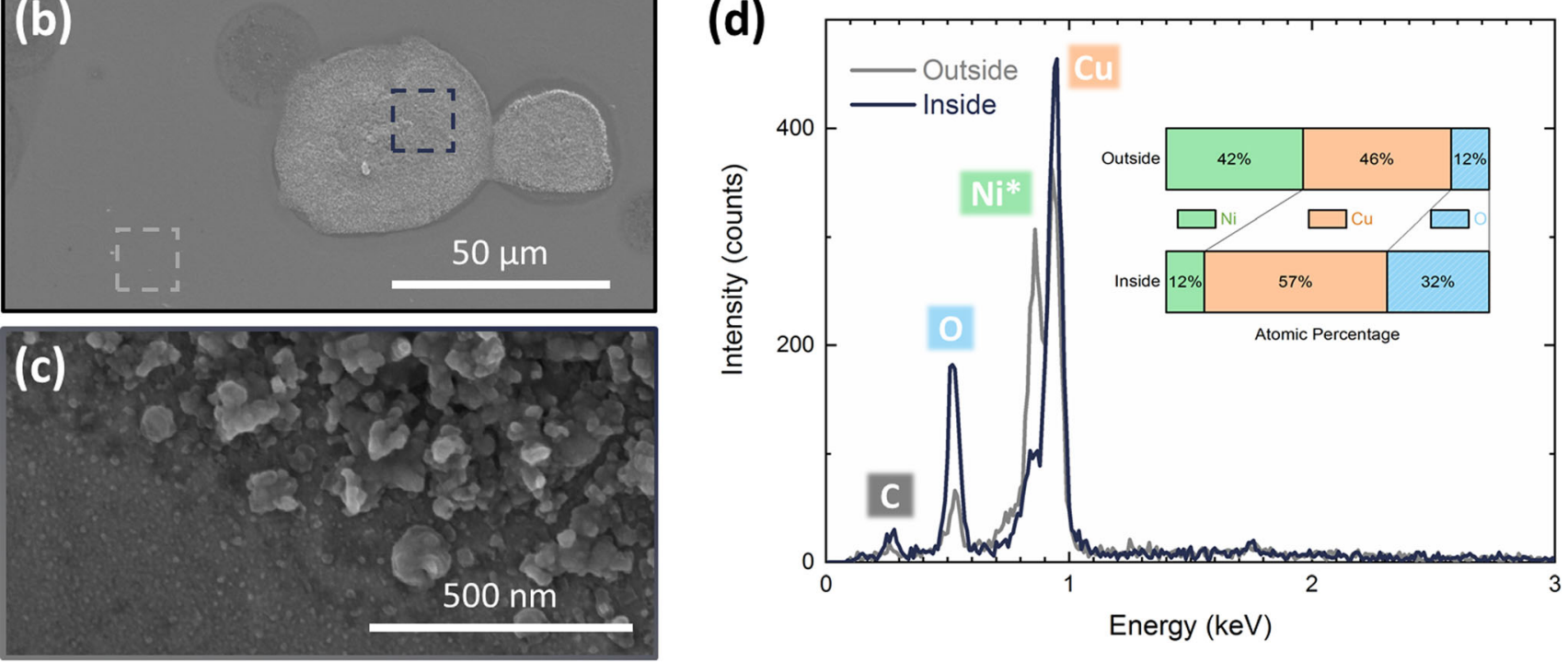

Figure 4 High resolution GIXRD results (a) of $250{ }^{\circ} \mathrm{C}$ heattreated coupons ("High $\mathrm{Cu} \mathrm{HT"} \mathrm{and} \mathrm{"Low} \mathrm{Cu} \mathrm{HT}$ ") and their original as-deposited coupons ("High $\mathrm{Cu}$ " and "Low $\mathrm{Cu}$ " that have been shown in Fig. 1) for comparison. $\mathrm{Cu}_{2} \mathrm{O}$ (JCPDS\#75-1531) and $\mathrm{NiO}$ (JCPDS\#04-0835) were applied to index the additional peaks. Enlarged spectra at the right side compare the positions of (111) and (200) diffractions with pure copper (JCDPS\#04-0836).

It should be noted that, although in the present work, Copper Alloys Type I is represented by the High $\mathrm{Cu}$ whilst Copper Alloys Type II by the Low $\mathrm{Cu}$, alloys with relatively lower copper contents do not necessarily always exhibit a poorer antibacterial efficacy [26, 39]. In other words, whether to oxidise an alloy or not should rely on its intrinsic

Representative SEM image (b) and high resolution SEM image (c) from the edge of two different regions found on the Low $\mathrm{Cu}$ HT. EDS spectra (d) were collected from the regions that marked by squares in (b), with inset indicating the average quantitative results based on the data shown in SI Fig. 5. The label of Ni is marked with star in order to remind the readers of the likely overlap between NiL and CuL.

antibacterial efficiency (which can be measured from trials), but not simply on its chemical composition (e.g. how high the copper content is).

The proof of concept presented in this work was accomplished by $\mathrm{Cu}-\mathrm{Ni}$ co-sputtered thin films, because sputtering is without a doubt one of the most effective and effortless methods to obtain a defined 


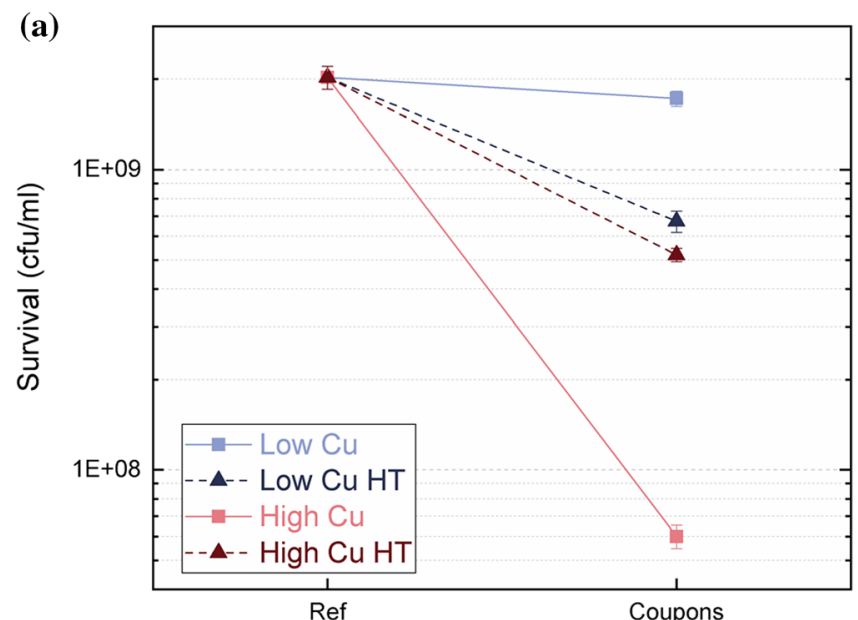

Figure 5 Antibacterial efficiency tests with E. coli on the $250{ }^{\circ} \mathrm{C}$ heat-treated coupons ("High $\mathrm{Cu} \mathrm{HT}$ " and "Low $\mathrm{Cu} \mathrm{HT}$ ") and their original as-deposited coupons ("High $\mathrm{Cu}$ " and "Low $\mathrm{Cu}$ "): (a) surviving colony-forming units and (b) the reduction rate in

surface with certain chemical composition or crystallinity. Many recent studies have applied this method to design functional surfaces and explored their antibacterial potentials [14, 17, 18]. But the very same idea is certainly applicable or even more meaningful in bulk copper alloys that can be fabricated in conventional metallurgical ways, no matter whether it is with commercial alloying elements or newly developed compositions [40, 41]. Its adaptability to a wide range of existing commercial copper alloys is worth being emphasised in the future studies.

Meanwhile, exclusive formation of $\mathrm{Cu}_{2} \mathrm{O}$ could be a challenge, just like the formation of $\mathrm{NiO}$ on the Low $\mathrm{Cu}$ HT shown in this study. One could also imagine as more/different alloying elements are included, undesirable by-products could form during oxidation process [42], undermining the coverage of antibacterial $\mathrm{Cu}_{2} \mathrm{O}$ or even suppressing its formation. Extensive investigation is thus needed in the selection of alloy composition in each applying scenario, even though coexistence of oxides might be inevitable subject to the oxygen affinity. Suitable temperature (as already shown in the present work) together with ambience composition might be two important parameters in guiding a desirable oxidation process. Nevertheless, apart from thermal oxidation, there are also other feasible approaches to introduce oxide that might be adapted accordingly, e.g. anodic oxidation [43] or laser surface treatment [32, 44, 45].

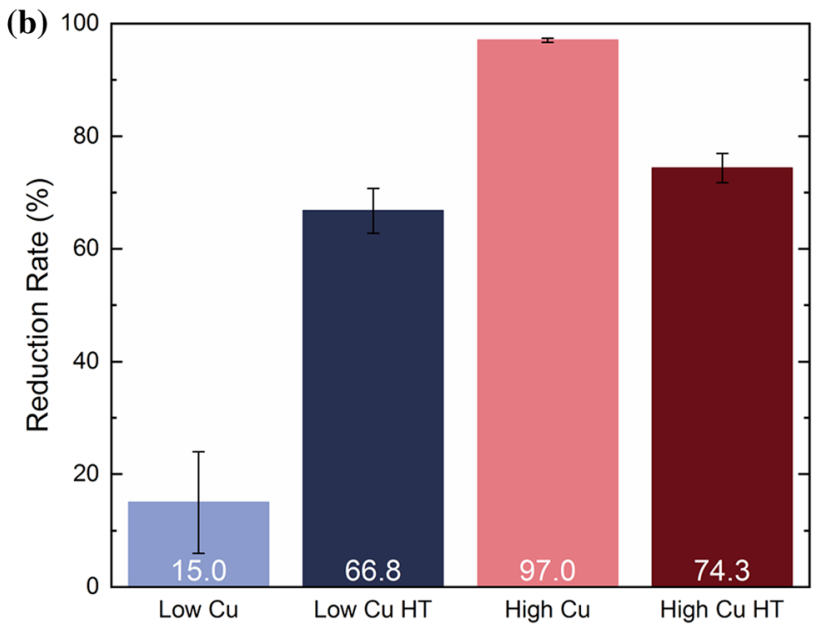

$1 \mathrm{~h}$. The cfu obtained from the original suspension is set as the negative control. The error bars indicate the standard deviation calculated from three measurements. The straight lines in (a) are only added for guiding the eyes.

No matter which oxidation method is selected, there are other features of the oxidised layer that are essential to application and therefore should also be examined if possible. One of them is the horizontal homogeneity of oxidation. Localised strong oxidation spots that are observed in this work, however, did not introduce too much concern in antibacterial efficiency test, as it actually represents inhomogeneity in depth whilst the droplet method for $1 \mathrm{~h}$ is an evaluation based on the global antibacterial performance of the outermost surface in short term. Moreover, only if the amount of copper released into the droplet is sufficient to deactivate the microbes, the locations where release occurs could be less important. But this may not always suit the actual scenarios: there might be no aqueous environment covering the entire surface, and therefore it is important to ensure every position that is contaminated by microbes can present equally excellent antibacterial effect. In addition to chemical composition, homogeneity could be required in other aspects such as microstructure and micro/nano-roughness. To better investigate the localised antibacterial behaviour, recently developed tests with dry or quasi-dry inoculum [46, 47] are certainly important alternatives.

On the other hand, inhomogeneity in depth, namely the effective oxidation depth is still an important variable. Usually, one advantage of applying copper and its alloys in daily touched surfaces is their quasi self-healing properties: abrasioncorrosion introduced by touching or cleaning [48] 


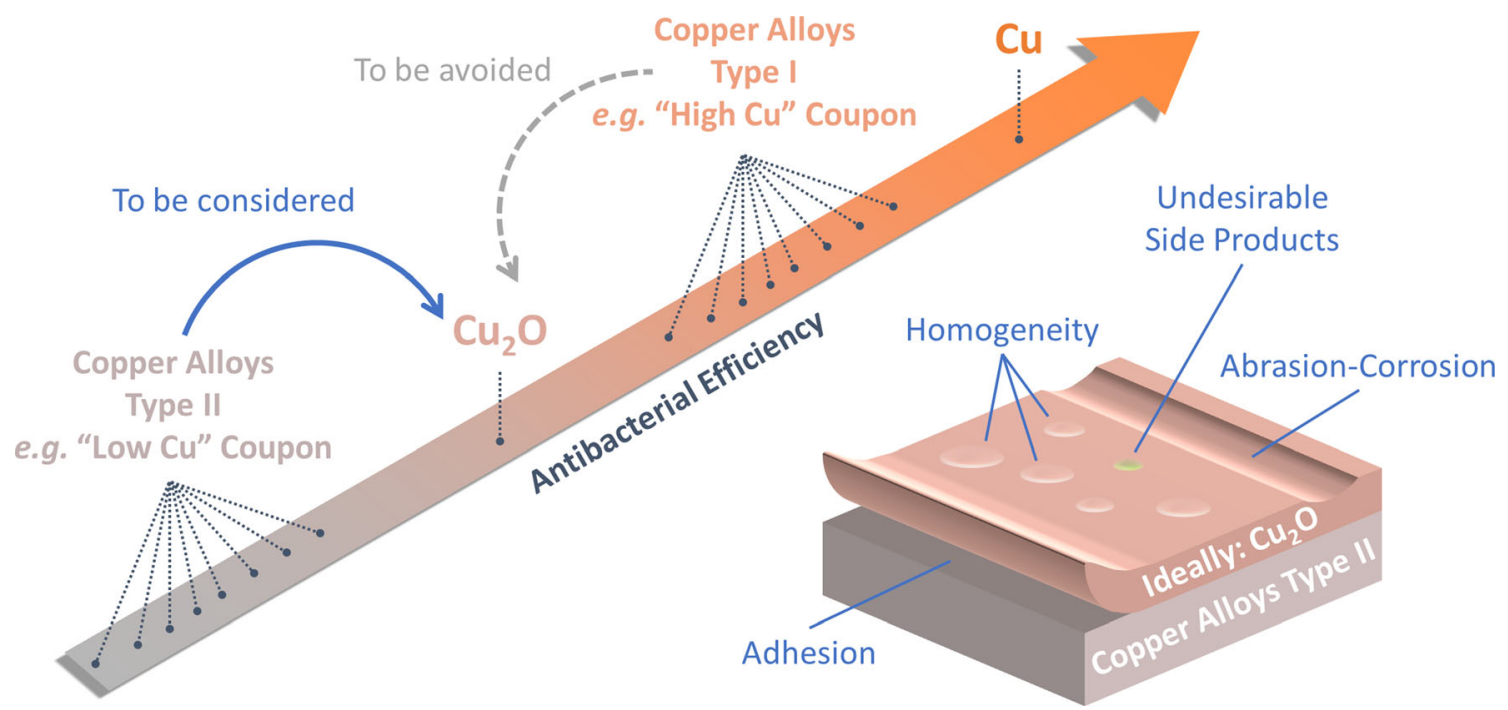

Figure 6 Schematic illustration of the potential of oxidation in altering the antibacterial efficiency of copper alloys and some practical insights of this concept.

could help releasing the topmost layer as well as the adhered microbes. This exposes the "new" surface underneath, maintaining the similar antibacterial efficacy. However, when surface oxidation is applied, the desired antibacterial effect only exists in the oxidised part, meaning within a certain depth. It is therefore important to evaluate the loss rate of the oxides in each specific circumstance in order to determine the desired depth of oxidation for an aimed lifespan. Along with this perspective, adhesion of the oxidised layer should be assessed or improved when necessary, since weak adhesion might cause early failure of the antibacterial layer.

Furthermore, adoption of oxidation strategy also shifts the mechanism of antibacterial copper ion release: from corrosion of the original metallic phases [49] to dissolution of $\mathrm{Cu}_{2} \mathrm{O}$ [21], which can be influenced by temperature, $\mathrm{pH}$ value, etc. [50]. As a result, specifying the environmental factors in the evaluations will ensure much applicable implication and persuasive conclusion. Given that the outermost surface will be oxidised on purpose, the deterioration induced by atmospheric corrosion might not be as troublesome as that on the metallic copper surfaces [10, 42], but it could still be worthwhile tracking the stability of the oxidised surface, e.g. together with daily disinfection events [51].

Last but not the least, although it was only the antibacterial efficiency against $E$. coli that was investigated in the present study, copper surfaces have actually shown capability against a very broad range of bacteria [3, 7, 52], viruses [53-55], and fungi $[25,52,56]$. Therefore, the strategy proposed here is also encouraging in many scenarios where the general antimicrobial property is needed.

\section{Conclusion}

Thermal oxidation of $\mathrm{Cu}-\mathrm{Ni}$ co-sputtered thin films are served as examples to illustrate the potential roles of oxidation on antibacterial copper alloy surfaces. Some concluding remarks are listed as follows:

- Critical oxidation temperature depends on the copper content of the thin films. To form a layer of $\mathrm{Cu}_{2} \mathrm{O}$ on the surface in $20-24 \mathrm{~h}$, thin films with higher copper content (92 at.\%) require only $200{ }^{\circ} \mathrm{C}$, whilst a relatively higher temperature $\left(250^{\circ} \mathrm{C}\right)$ is required for those with lower copper content (55 at.\%).

- Although the atomic percentage of oxygen increased globally, some relatively strongly oxidised regions are found on both oxidised thin films, together with distinct sub-micron topography.

- Successful oxidation of the investigated thin films introduces dramatic changes in their antibacterial performance against E. coli evaluated by the droplet method: the high copper content thin films get degraded (reduction rate in $1 \mathrm{~h}$ declines from $97.0 \%$ to $74.3 \%$ ) whilst the low copper 
content ones get significantly improved (from $15.0 \%$ to $66.8 \%$ ).

- The concept of enhancing antibacterial efficiency of less effective copper alloy surfaces by means of surface oxidation is verified.

\section{Acknowledgements}

The authors would like to thank Johannes Webel for the meaningful introduction in SEM image classification, and Dr. Christoph Pauly for constructive discussion in interpretation of EDS results.

\section{Author contribution}

JL contributed to conceptualization, investigation, validation, visualization, and writing - original draft. AA contributed to investigation, validation, visualization, and writing - original draft. J-FP contributed to funding acquisition, resources, supervision, and writing - review and editing. FM contributed to funding acquisition, resources, and supervision.

\section{Funding}

This study was supported by Erasmus Mundus Joint European Doctoral Programme in Advanced Materials Science and Engineering (DocMASE, 512225-12010-1-DE-EMJD, European Commission) and the PhD-Track-Programme (PhD02-14, Franco-German University). A.A. has been funded by the German Aerospace Center-Space Administration (DLR) within the project "Investigation of antimicrobial metal surfaces under space conditions-An effective strategy to prevent microbial biofilm formation" (Project Number 50WB1930), and German Research Foundation (DFG) within the project "Controlled bacterial interaction to increase the antimicrobial efficiency of copper surfaces" (Project Number 415956642). Open Access funding enabled and organized by Projekt DEAL.

\section{Data availability}

The data that support the findings of this study are available from the corresponding author on request.

\section{Declarations}

Conflict of interest The authors declare that they have no conflict of interest.

Supplementary Information: The online version contains supplementary material available at http s://doi.org/10.1007/s10853-022-06879-5.

Open Access This article is licensed under a Creative Commons Attribution 4.0 International License, which permits use, sharing, adaptation, distribution and reproduction in any medium or format, as long as you give appropriate credit to the original author(s) and the source, provide a link to the Creative Commons licence, and indicate if changes were made. The images or other third party material in this article are included in the article's Creative Commons licence, unless indicated otherwise in a credit line to the material. If material is not included in the article's Creative Commons licence and your intended use is not permitted by statutory regulation or exceeds the permitted use, you will need to obtain permission directly from the copyright holder. To view a copy of this licence, visit http://creativecommons.org/licen ses/by $/ 4.0 /$.

\section{References}

[1] Michels H, Moran W, Michel J (2008) Antimicrobial properties of copper alloy surfaces, with a focus on hospitalacquired infections. Int J Metalcast 2:47-56

[2] Salgado CD, Sepkowitz KA, John JF, Cantey JR, Attaway HH, Freeman KD, Sharpe PA, Michels HT, Schmidt MG (2013) Copper surfaces reduce the rate of healthcare-acquired infections in the intensive care unit. Infect Control Hosp Epidemiol 34:479-486

[3] Michels HT, Keevil CW, Salgado CD, Schmidt MG (2015) From laboratory research to a clinical trial: copper alloy surfaces kill bacteria and reduce hospital-acquired infections. HERD Health Environ Res Des J 9:64-79

[4] Souli M, Antoniadou A, Katsarolis I, Mavrou I, Paramythiotou E, Papadomichelakis E, Drogari-Apiranthitou M, Panagea T, Giamarellou H, Petrikkos G, Armaganidis A (2017) Reduction of environmental contamination with multidrug-resistant bacteria by copper-alloy coating of surfaces in a highly endemic setting. Infect Control Hosp Epidemiol 38:765-771 
[5] Ibrahim Z, Petrusan AJ, Hooke P, Hinsa-Leasure SM (2018) Reduction of bacterial burden by copper alloys on hightouch athletic center surfaces. Am J Infect Control 46:197-201

[6] Różańska A, Chmielarczyk A, Romaniszyn D, Majka G, Bulanda M (2018) Antimicrobial effect of copper alloys on Acinetobacter species isolated from infections and hospital environment. Antimicrob Resist Infect Control 7:10

[7] Dauvergne E, Lacquemant C, Adjidé C, Mullié C (2020) Validation of a worst-case scenario method adapted to the healthcare environment for testing the antibacterial effect of brass surfaces and implementation on hospital antibiotic-resistant strains. Antibiotics 9:245

[8] Macomber L, Imlay JA (2009) The iron-sulfur clusters of dehydratases are primary intracellular targets of copper toxicity. Proc Natl Acad Sci 106:8344-8349

[9] Santo CE, Taudte N, Nies DH, Grass G (2008) Contribution of copper ion resistance to survival of $E$. coli on metallic copper surfaces. Appl Environ Microbiol 74:977-986

[10] Luo J, Hein C, Pierson J-F, Mücklich F (2020) Sodium chloride assists copper release, enhances antibacterial efficiency, and introduces atmospheric corrosion on copper surface. Surf Interfaces 20:100630

[11] Davis JR (2001) Copper and copper alloys. ASM international, Ohio

[12] Hong R, Kang TY, Michels CA, Gadura N (2012) Membrane lipid peroxidation in copper alloy-mediated contact killing of E. coli. Appl Environ Microbiol 78:1776-1784

[13] Kocaman A, Keles O (2019) Antibacterial efficacy of wire arc sprayed copper coatings against various pathogens. J Therm Spray Technol 28:504-513

[14] Kang Y, Park J, Kim D-W, Kim H, Kang Y-C (2016) Controlling the antibacterial activity of $\mathrm{CuSn}$ thin films by varying the contents of Sn. Appl Surf Sci 389:1012-1016

[15] Ciacotich N, Din RU, Sloth JJ, Møller P, Gram L (2018) An electroplated copper-silver alloy as antibacterial coating on stainless steel. Surf Coat Technol 345:96-104

[16] Villapún VM, Lukose CC, Birkett M, Dover LG, González S (2018) Tuning the antimicrobial behaviour of Cu85Zr15 thin films in "wet" and "dry" conditions through structural modifications. Surf Coat Technol 350:334-345

[17] Etiemble A, Der Loughian C, Apreutesei M, Langlois C, Cardinal S, Pelletier JM, Pierson JF, Steyer P (2017) Innovative $\mathrm{Zr}-\mathrm{Cu}-\mathrm{Ag}$ thin film metallic glass deposed by magnetron PVD sputtering for antibacterial applications. J Alloy Compd 707:155-161

[18] Comby-Dassonneville S, Venot T, Borroto A, Longin E, der Loughian C, ter Ovanessian B, Leroy M-A, Pierson J-F, Steyer P (2021) ZrCuAg thin-film metallic glasses: toward biostatic durable advanced surfaces. ACS Appl Mater Interfaces 13:17062-17074

[19] Hans M, Erbe A, Mathews S, Chen Y, Solioz M, Mücklich F (2013) Role of copper oxides in contact killing of bacteria. Langmuir 29:16160-16166

[20] Hassan IA, Parkin IP, Nair SP, Carmalt CJ (2014) Antimicrobial activity of copper and copper(i) oxide thin films deposited via aerosol-assisted CVD. J Mater Chem B 2:2855-2860

[21] Luo J, Hein C, Pierson J-F, Mücklich F (2019) Early-stage corrosion, ion release, and the antibacterial effect of copper and cuprous oxide in physiological buffers: Phosphate-buffered saline vs Na-4-(2-hydroxyethyl)-1-piperazineethanesulfonic acid. Biointerphases 14:061004

[22] Katwal R, Kaur H, Sharma G, Naushad M, Pathania D (2015) Electrochemical synthesized copper oxide nanoparticles for enhanced photocatalytic and antimicrobial activity. J Ind Eng Chem 31:173-184

[23] Ekthammathat N, Thongtem T, Thongtem S (2013) Antimicrobial activities of $\mathrm{CuO}$ films deposited on $\mathrm{Cu}$ foils by solution chemistry. Appl Surf Sci 277:211-217

[24] Eswar NK, Gupta R, Ramamurthy PC, Madras G (2018) Influence of copper oxide grown on various conducting substrates towards improved performance for photoelectrocatalytic bacterial inactivation. Mol Catal 451:161-169

[25] Shim G-I, Kim S-H, Eom H-W, Choi S-Y (2015) Concentration- and roughness-dependent antibacterial and antifungal activities of $\mathrm{CuO}$ thin films and their $\mathrm{Cu}$ ion cytotoxicity and elution behavior. $\mathrm{J}$ Ind Microbiol Biotechnol 42:735-744

[26] Horton DJ, Ha H, Foster LL, Bindig HJ, Scully JR (2015) Tarnishing and $\mathrm{Cu}$ ion release in selected copper-base alloys: implications towards antimicrobial functionality. Electrochim Acta 169:351-366

[27] Walkowicz M, Osuch P, Smyrak B, Knych T, Rudnik E, Cieniek Ł, Różańska A, Chmielarczyk A, Romaniszyn D, Bulanda M (2018) Impact of oxidation of copper and its alloys in laboratory-simulated conditions on their antimicrobial efficiency. Corros Sci 140:321-332

[28] Schindelin J, Arganda-Carreras I, Frise E, Kaynig V, Longair M, Pietzsch T, Preibisch S, Rueden C, Saalfeld S, Schmid B, Tinevez J-Y, White DJ, Hartenstein V, Eliceiri K, Tomancak P, Cardona A (2012) Fiji: an open-source platform for biological-image analysis. Nat Methods 9:10999

[29] Molteni C, Abicht HK, Solioz M (2010) Killing of bacteria by copper surfaces involves dissolved copper. Appl Environ Microbiol 76:4099-4101

[30] Wagner C (1952) Theoretical analysis of the diffusion processes determining the oxidation rate of alloys. J Electrochem Soc 99:369 
[31] Heinemann K, Rao DB, Douglass DL (1977) In situ oxidation studies on (001) copper-nickel alloy thin films. Oxid Met 11:321-334

[32] Selvamani V, Zareei A, Elkashif A, Maruthamuthu MK, Chittiboyina S, Delisi D, Li Z, Cai L, Pol VG, Seleem MN, Rahimi R (2020) Hierarchical micro/mesoporous copper structure with enhanced antimicrobial property via laser surface texturing. Adv Mater Interfaces 7:1901890

[33] Müller DW, Lößlein S, Terriac E, Brix K, Siems K, Moeller R, Kautenburger R, Mücklich F (2021) Increasing antibacterial efficiency of $\mathrm{Cu}$ surfaces by targeted surface functionalization via ultrashort pulsed direct laser interference patterning. Adv Mater Interfaces 8:2001656

[34] Wallwork GR (1976) The oxidation of alloys. Rep Prog Phys 39:401-485

[35] Lawless KR (1974) The oxidation of metals. Rep Prog Phys 37:231-316

[36] Unutulmazsoy Y, Cancellieri C, Chiodi M, Siol S, Lin L, Jeurgens LPH (2020) In situ oxidation studies of $\mathrm{Cu}$ thin films: growth kinetics and oxide phase evolution. J Appl Phys 127:065101

[37] Noyce JO, Michels H, Keevil CW (2006) Potential use of copper surfaces to reduce survival of epidemic meticillinresistant Staphylococcus aureus in the healthcare environment. J Hosp Infect 63:289-297

[38] Hahn C, Hans M, Hein C, Mancinelli RL, Mucklich F, Wirth R, Rettberg P, Hellweg CE, Moeller R (2017) Pure and oxidized copper materials as potential antimicrobial surfaces for spaceflight activities. Astrobiology 17:1183-1191

[39] Różańska A, Chmielarczyk A, Romaniszyn D, Sroka-Oleksiak A, Bulanda M, Walkowicz M, Osuch P, Knych T (2017) Antimicrobial properties of selected copper alloys on Staphylococcus aureus and E. coli in different simulations of environmental conditions: with vs without organic contamination. Int J Environ Res Public Health 14:813

[40] Fowler L, Janson O, Engqvist H, Norgren S, Öhman-Mägi C (2019) Antibacterial investigation of titanium-copper alloys using luminescent Staphylococcus epidermidis in a direct contact test. Mater Sci Eng, C 97:707-714

[41] Tao SC, Xu JL, Yuan L, Luo JM, Zheng YF (2020) Microstructure, mechanical properties and antibacterial properties of the microwave sintered porous $\mathrm{Ti}-3 \mathrm{Cu}$ alloys. J Alloys Compd 812:152142

[42] Chang T, Butina K, Herting G, Rajarao GK, Richter-Dahlfors A, Blomberg E, Wallinder IO, Leygraf C (2021) The interplay between atmospheric corrosion and antimicrobial efficiency of $\mathrm{Cu}$ and $\mathrm{Cu} 5 \mathrm{Zn} 5 \mathrm{Al1} \mathrm{Sn}$ during simulated hightouch conditions. Corros Sci 185:109433

[43] Kunze J, Maurice V, Klein LH, Strehblow H-H, Marcus P (2001) In situ scanning tunneling microscopy study of the anodic oxidation of $\mathrm{Cu}(111)$ in $0.1 \mathrm{M} \mathrm{NaOH}$. J Phys Chem B 105:4263-4269

[44] Villapún VM, Qu B, Lund PA, Wei W, Dover LG, Thompson JR, Adesina JO, Hoerdemann C, Cox S, González S (2020) Optimizing the antimicrobial performance of metallic glass composites through surface texturing. Mater Today Commun 23:101074

[45] Müller DW, Holtsch A, Lößlein S, Pauly C, Spengler C, Grandthyll S, Jacobs K, Mücklich F, Müller F (2020) Indepth investigation of copper surface chemistry modification by ultrashort pulsed direct laser interference patterning. Langmuir 36:13415-13425

[46] McDonald M, Wesgate R, Rubiano M, Holah J, Denyer SP, Jermann C, Maillard JY (2020) Impact of a dry inoculum deposition on the efficacy of copper-based antimicrobial surfaces. J Hosp Infect 106:465-472

[47] Chang T, Sepati M, Herting G, Leygraf C, Rajarao GK, Butina K, Richter-Dahlfors A, Blomberg E, Wallinder IO (2021) A novel methodology to study antimicrobial properties of high-touch surfaces used for indoor hygiene applications - a study on Cu metal. PLoS ONE 16:e0247081

[48] Bryce EA, Velapatino B, Khorami HA, Donnelly-Pierce T, Wong T, Dixon R, Asselin E (2020) In vitro evaluation of antimicrobial efficacy and durability of three copper surfaces used in healthcare. Biointerphases 15:011005

[49] Luo J, Hein C, Pierson J-F, Mücklich F (2019) Localised corrosion attacks and oxide growth on copper in phosphatebuffered saline. Mater Charact 158:109985

[50] Palmer D (2011) Solubility measurements of crystalline $\mathrm{Cu} 2 \mathrm{O}$ in aqueous solution as a function of temperature and pH. J Solut Chem 40:1067-1093

[51] Steinhauer K, Meyer S, Pfannebecker J, Teckemeyer K, Ockenfeld K, Weber K, Becker B (2018) Antimicrobial efficacy and compatibility of solid copper alloys with chemical disinfectants. PLoS ONE 13:e0200748

[52] Mehtar S, Wiid I, Todorov SD (2008) The antimicrobial activity of copper and copper alloys against nosocomial pathogens and Mycobacterium tuberculosis isolated from healthcare facilities in the Western Cape: an in-vitro study. J Hosp Infect 68:45-51

[53] Noyce JO, Michels H, Keevil CW (2007) Inactivation of influenza a virus on copper versus stainless steel surfaces. Appl Environ Microbiol 73:2748-2750

[54] Warnes SL, Keevil CW (2013) Inactivation of norovirus on dry copper alloy surfaces. PLoS ONE 8:e75017

[55] van Doremalen N, Bushmaker T, Morris DH, Holbrook MG, Gamble A, Williamson BN, Tamin A, Harcourt JL, Thornburg NJ, Gerber SI, Lloyd-Smith JO, de Wit E, Munster VJ (2020) Aerosol and surface stability of SARS-CoV-2 as compared with SARS-CoV-1. N Engl J Med 382:1564-1567 
[56] Lucas MDI, Botef I, Reid RG, van Vuuren SF (2020) Laboratory-based study of novel antimicrobial cold spray coatings to combat surface microbial contamination. Infect Control Hosp Epidemiol 41:1378-1383
Publisher's Note Springer Nature remains neutral with regard to jurisdictional claims in published maps and institutional affiliations. 